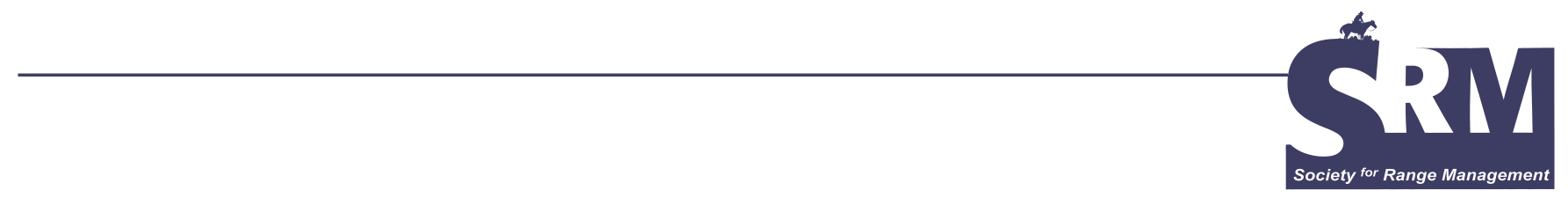

\title{
Drought Effects on the Ranching Industry in Southeastern Colorado
}

\section{By Mary M. Miller}

$\mathrm{I}$ n 2002, Colorado was in the grip of a multiyear drought - the worst and most widespread on record, according to Nolan Doesken, Colorado Assistant State Climatologist. It had severe effects on agriculture, tourism, recreation, commerce, water supplies, and wildlife.

Approximately 60\%, or 14.5 million, of Colorado's 24 million acres of privately owned rangeland were severely impacted. Recovery has been slow.

In 2002, Colorado ranchers either sold or moved record livestock numbers to other states for grazing. Colorado saw a $60 \%$ decrease in the mother cow herd that year. The drought jeopardized the integrity of rangeland resources besides having negative economic impacts on Colorado ranches and rural communities.

Looking back, the drought forced changes in most ranching operations in southeastern Colorado. The types of changes varied from altering rangeland-management practices to one or both spouses taking jobs off the ranch to supplement the ranch income to selling one's entire mother cow herd and getting out of ranching.

Bill Hancock, Colorado State University Cooperative Extension (CSU CE) agent in Crowley and Otero counties, and Roy Roath, CSU CE Rangeland Management Specialist, both agreed that good times don't create teachable moments, the bad times do. Both worked with the US Department of Agriculture Natural Resources Conservation Service (NRCS) offices and local conservation districts plus other conservation groups in southeastern Colorado in sponsoring workshops designed to provide ranchers with information on how to recover from the drought. Topics covered the natural resources, financial resources, and animal resources on a ranch.

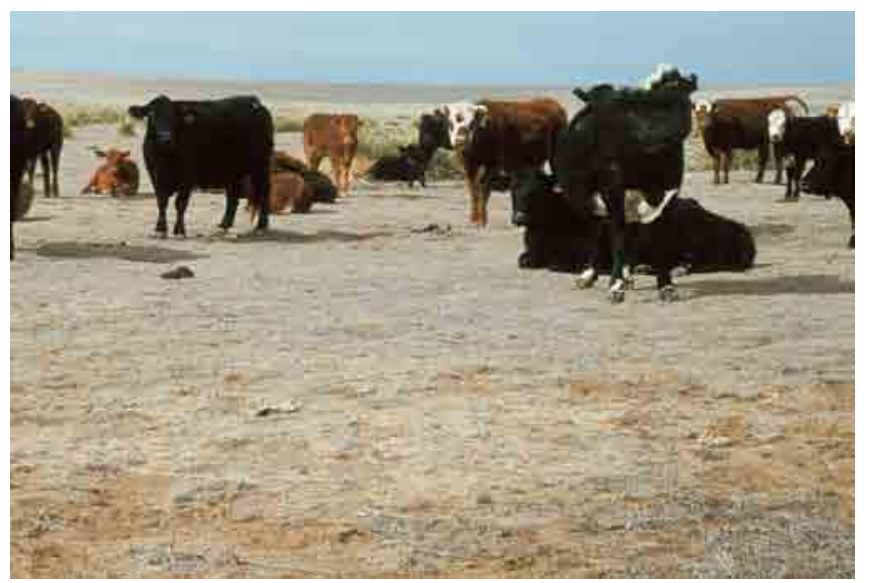

Cattle on drought-stricken rangeland in Otero County, Colorado. USDANRCS photograph by Mary Miller.

In the end, ranchers made decisions depending on their own personal situation. Bill Gray, president-elect of the Colorado Cattlemen's Association, has rangeland near Ordway, Colorado, and near Arlington, Colorado. The cow herd on his ranches has been in his family for more than 100 years. From the spring of 2002 to that fall, he destocked half the herd due to the drought. "When I had to sell those cows, I could hardly sit there," said Gray. "It's hard to even talk about it now."

Gray said that, due to the changes he made plus some good moisture this past year, his rangeland is beginning to recover. "You have to take care of the grass first," he said. "In the end, you can always buy genetics; you can't buy grass."

Another rancher in Bent County agrees with Gray about taking care of the grass. Preston Grover said, "We are grass 


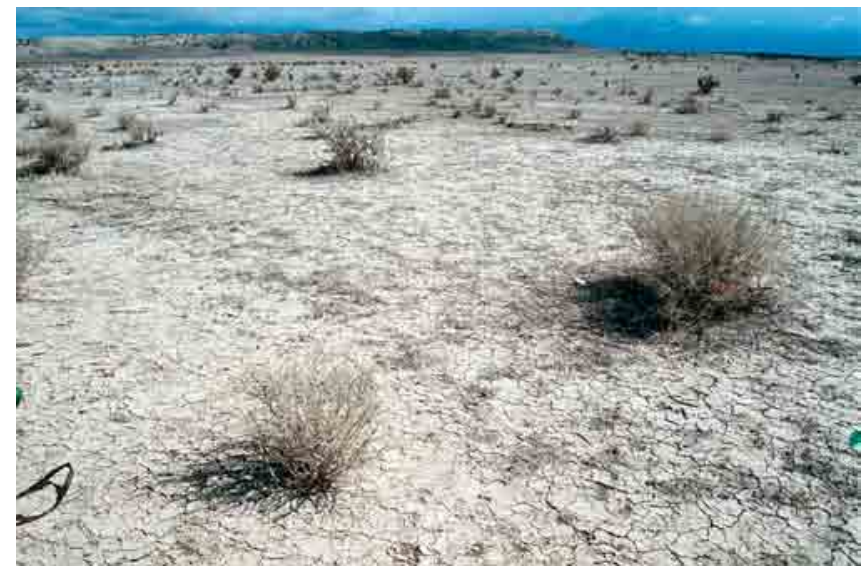

Drought-stricken rangeland in southeastern Colorado. USDA-NRCS photograph by Mary Miller.

farmers." Besides knowing what the rangeland can handle as far as a stocking rate, Grover also believes that ranchers need to practice a deferred rotational grazing system. He feels that, by having a planned grazing system, he gives his rangeland the rest periods it needs to recover. Even though he also was hard hit by the drought, he sees improvement in his rangeland due to his management practices.

Roy Armstrong and Dave Kitch own Great Western Grazing Association near Fowler, Colorado, and United Feeders near Rocky Ford, Colorado. Having a feedlot and a ranch provided them some flexibility to make it through the drought. "One of the benefits of having a feedlot in conjunction with the ranch is we have flexibility - we can go back and forth," said Armstrong.

Armstrong feels the 2002 drought was devastating to the ranching industry in the southeastern corner of Colorado. He said that, in the spring of that year, they stocked their ranch at $50 \%$ capacity, but by July 1 , they started moving cattle to the feedlot due to the lack of moisture on the rangeland. Many of their past feedlot clients also put their cattle into the feedlot much earlier in the year.

Prior to the drought, Armstrong and Kitch had worked with the local NRCS office through the old Great Plains Conservation Program to install watering facilities and cross-fencing for their rotational grazing system.

"We were probably better off than other ranchers who practiced season-long grazing going into the drought," said Kitch. "Roy is the main manager of the ranch. We are very conservative in our stocking rates." Even with a rotational system, Armstrong and Kitch only stocked their rangeland at $40 \%$ in 2003 and $50 \%-70 \%$ in 2004.

Grover, Armstrong, and Kitch differ from Gray in that they buy and sell either cows or yearlings, so they do not have

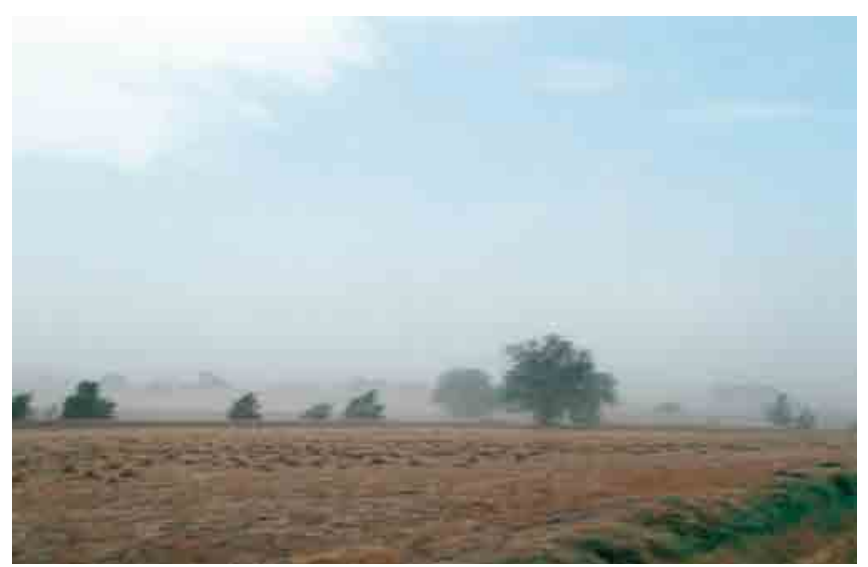

May 2002 windstorm in southeastern Colorado. USDA-NRCS photograph by Mary Miller.

the time and money spent on genetics and a main mother cow herd that Gray and other ranchers had.

Hancock and Roath, in cooperation with the NRCS, continue their work to help ranchers improve their grazing management and understanding of what the rangeland needs to recover from the 2002 drought. Roath says that some ranchers had more grass than they did water, so they are replanning their watering facilities so that, the next time it gets droughty, they are better prepared for a rotational grazing system. "They need to plan for the worst-case scenario and appreciate it when they ever get anything better than that," said Hancock.

The various agency grazing specialists believe that those ranchers with an established rotational grazing system in place minimized the drought's effects, were better prepared to weather the drought, and came out of the drought in better shape to restock the rangeland resource.

Armstrong believes that, in order to be prepared for tough years, ranchers need to be proactive in lowering stocking rates even in the early stages of a drought and need to be flexible within their grazing management system. "Have a Plan A and Plan B in your grazing system," said Armstrong.

To be ready for the next drought, Gray will improve his rotational grazing system, monitor his rangeland more, and just understand that this part of the country is always on the verge of a drought.

"In general, I do not think we were prepared for this drought," said Grover. "Hopefully, more of us will be better prepared for the next one."

The author is Area Public Affairs Specialist, USDA Natural Resources Conservation Service, La Junta, CO. 